\title{
Political Economy of the West and Africa under- Development Sydrome in the $21^{\text {st }}$ Century
}

\author{
Micah, Ezekiel Elton Michael ${ }^{1}$, Akinwunmi Adeboye, A $^{2}$, Aghemelo, Austin Thomas ${ }^{3}$ \\ ${ }^{1}$ Department of Business Administration, Nassrawa State University, Keff,-Nigeria \\ ${ }^{2}$ Department of Banking \& Finance, Achievers University, Owo Ondo State, Nigeria \\ ${ }^{3}$ Department of Political Science, Ambrose Alli University, Ekpoma, Edo State, Nigeria
}

\begin{abstract}
Africa is the richest continent in the world in terms of natural resources, yet it is the poorest continent in terms of socio-economic development. The story of Africa is that of a continent with a paradox of being so rich, yet very poor. There is the disconcerting fact that Africa harbours overwhelming majority of the least developed countries of the world which United Nation regards as the Poorest. In spite of its rich resources-endowment, a disproportion number of people in the population of Africa are known to be undernourished and under-privileged. Colonialism has impacted the political and economic conditions of the contemporary Africa. Post-independence African states are a western model. Therefore, the focus of this paper is to examine the role of political economy of the West on the under-development of Africa. It was discovered that, the rising profile of Africa in the world socio-political and economy was suddenly truncated through its contact with the outside world. The preceding result of the research also, revealed that, what was called 'the development of Africa' by the colonialists was a cynical short-hand expression for 'the intensification of colonial exploitation in Africa to develop capitalist Europe'. Hence, African resources were extensively exploited by colonizers, thereby rendering Africa economically weak and looser in its interaction with the global economy. However, this paper concludes that colonialism and imperialism had played negative impact on Africa's development. In offering this view, the paper then drawn attention to the way that previous African development was blunted, halted and turned back by the capitalist Europe. The paper then, suggests that much of the conventional wisdom regarding on how best to address African development and poverty is not only misguided but often harmful by certain policies. Hence, other policy issues were recommended which constitute imperative pre-requisite for the attainment of development in the continent of Africa.
\end{abstract}

Keywords: Political Economy, Development, Under-development, The West, Africa

\section{INTRODUCTION}

What caused Africa's underdevelopment is a complex issue. Europe's past (and present) exploitation of Africa played a significant part. Before the Europeans arrived in Africa, Africa had vibrant economic, social and political structures. These were severely disrupted by Europeans to create wealth for themselves. It is well known that Africa is falling behind the rest of the world in terms of economic wellbeing. Even though global poverty is declining due to rapid economic growth in India, China, and other parts of the world, Africa's contribution to this decline is disappointing and absolute poverty in many of the African nations is on the increase.

The African condition of underdevelopment has today manifested in the increasing inability of African countries to provide the basic essentials of life to their citizens. The problem of hunger, unemployment, disease, illiteracy, socio-economic anxiety and insecurity, have tended to over-whelm as mass majority of the people, resulting in mass frustration, alienation and disorientation of the citizenry. The situation has been compounded by problems of repression and exploitation perpetrated by a decadent ruling class. The result is that today, African's contribution to global GDP and industrial output is not only infinitesimal, the Physical Quality of Life Index (PQLI) and other indicators of development in most acquisition, nature, uses, misuses or abuses, (Ojo, 1998). Today, we live in a World where many societies are extremely poor, while few others are exceedingly rich. In many countries in Africa, Asia and Latin America, millions of people are living in abject poverty. Lack of development has been said to be responsible for this appalling situation. What then is development? 
While some people see development as Industrialization and Modernity or even Westernization and its artifacts such as cars, trains, refrigerators, television, computers, phone-sets, radio, electricity, textiles, schools, tarred roads, et cetera, for others, development has come to mean the Millennium Development Goals (MDGs). In other words, to them, development is the eradication of extreme poverty and hunger, illiteracy, maternal and child mortality, malaria and HIV/AIDS, gender inequality, and so on. Development is often used in an exclusive economic sense - the justification being that the economy has a pervasive influence in all societies and also, the economy is itself an indicator of other socio-political features of a society. But, development is a multi-dimensional concept, thus it could be economic, political, social, cultural or even human.

The situation has been compounded by the problems of repression and exploitation perpetrated by decadent colonial masters. The most outstanding work to date, which examines the impact of colonial rule on development processes in Africa, in Walter Rodney's book How Europe underdeveloped Africa. The account given in this book show how Africa was robbed of her potentials, specifically through slave trade, colonialism, imperialist exploitation, (Ojo, 1998). Africa's current marginal position in the global economy must be placed in an historical context - i.e. it's colonial past and the manner in which the continent was integrated into the post-1945 world order. The continent is no stranger to the deleterious effects of globalization. More than any other region in the world, Africa has paid a high price for the globalizing policies of rival capitalist powers as they strived to expand the geographic bounds of capital. Starting with the slave trade in 1650 and continuing under colonial rule after the Berlin conference of 1884, the continent has been heavily drawn into the centers of capitalist accumulation, but always as a subordinate partner with the primary purpose of contributing to the development of the metropolitan powers. Mistaken interpretations of the causes of underdevelopment usually stem either from prejudiced thinking or from the error of believing that one can learn the answers by looking inside the underdeveloped economy. (The true explanation lies in seeking out the relationship between Africa and certain developed countries and in recognizing that it is a relationship of exploitation.

Man has always exploited his natural environment in order to make a living. At a certain point in time, there also arose the exploitation of man by man, in that a few people grew rich and lived well through the labour of others. Then a stage was reached by which people in one community called a nation exploited the natural resources and the labour of another nation and its people. Since underdevelopment deals with the comparative economics of nations, it is the last kind of exploitation that is of greatest interest here - i.e. the exploitation of nation by nation. One of the common means by which one nation exploits another and one that is relevant to Africa's external relations is exploitation through trade. When the terms of trade are set by one country in a manner entirely advantageous to itself, then the trade is usually detrimental to the trading partner. To be specific, one can take the export of agricultural produce from Africa and the import of manufactured goods into Africa from Europe, North America and Japan. The big nations establish the price of the agricultural products and subject these prices to frequent reductions. At the same time the price of manufactured goods is also set by them, along with the freight rates necessary for trade in the ships of those nations. The minerals of Africa also fall into the same category as agricultural produce as far as pricing is concerned. The whole import/export relationship between Africa and its trading partners is one of unequal exchange and of exploitation. The post-1945 world order has done very little to alter Africa's subordinate role in it (Carin, \& Fantu , 2008). Apart from the retroversion, and sometime outright denial of African history, the colonial state, being an illegitimate state, relied on the illegitimate use of force for its survival (Osaghae 1989:37; Ake, 1978; Mamdani, 2002). Amidst the ensuing deeply entrenched legitimacy crisis, the resort to violence became inevitable to accomplish its imperial objectives. At every stage and at every level, as Onimode (2000:73) has argued, colonialism was a massively violent encounter. Granted that the decolonization process has been completed in Africa, the substantive legacies of colonialism still endure (Mamadani, 2002; Osterhammel, 1997; Ekeh, 1983, 1975). They are manifest in the form of imported and transformed social structures, which today remain largely unchanged. The failure of African States to adapt these structures into African realities or to dismantle them, even in the face of glaring opportunities at independence, has remained a potent force in the neo-colonial enterprise. Up until today, as shown by its attributes of dependence, legitimacy crisis, underdevelopment, Africa remains a continent of crisis and contradiction (Osaghae, 1999, Onimode, 1983). All efforts to address the situation by African leaders have so far been feckless 
because the neo-colonial environment has been ably accommodated and enhanced by the enduring legacies of colonialism. This explains why today, Africa remains at the very nadir of development.

Recent pre-crisis real GDP growth rates suggest that Africa's economy was beginning to recover after the "lost" last quarter of the twentieth century), but not exclusively, to a strong commodity boom. Despite this growth upturn, the region remains mired in poverty, faces the most serious infrastructure gaps and retains a narrow export base, none of which is conducive to rapid and sustainable development.

Yet, when most other developing economies embarked on import-substituting industrialization in the 1930s (in Latin America) and the 1950s, Africa remained under colonial rule for much of the period, and well into the 1960s. Consequently, the import substitution phase in most of African Countries were relatively short, lasting barely a decade in many countries due to the lateness of independence and the early onset of economic slowdown owing to the oil shocks of the 1970s (Mkandawire, 1988). Import compression following the debt crisis constrained capacity utilization and investment, preventing many countries in Africa from adjusting positively to the changed global environment. In this context, trade liberalization, beginning in the 1980s, prematurely exposed African "infant" industries to global competition against much more mature industries. In addition, the global economic crisis of 2008 has had a severe impact on Africa. Growth decelerated significantly in 2009, endangering the limited progress made on the Millennium Development Goals (MDGs), especially poverty reduction (UNECA-AU, 2010). The wave of democratic reforms since the 1990s and the commodity price boom since 2001 lead many to believe that Africa could claim the 21 st century. In fact, following the commodity boom African economy grew by over 5\% on average for more than 6 years which was unprecedented in the history of the continent. Many argued that Africa needed about $7 \%$ annual average growth rate to achieve the Millennium Development Goals.

However, this hope was dashed when the global economic downturn abruptly ended the commodity price boom in mid 2008. As a result, African economic growth plummeted to less than $3 \%$ in 2009. The recent revival in oil and other commodity prices and signs of global economic resilience are causes for optimism. However, reduced capital inflows coupled with widening budget deficits in many African countries are sure to delay any hope for faster recovery. Apart from this, the current revival in commodity prices may be short lived. Commodity prices may settle at much lower equilibrium levels even after the global economic recovery dashing further any hope for faster economic growth recovery in Africa. One French Socialist writer, Pierre Jalée, proposes that to obtain a proper perspective of relations between developed countries and underdeveloped ones, two categories should be set up namely, imperialist and Socialist. The Socialist camp includes all countries big and small which have decided to break away from international capitalism. The imperialist camp contains not only the capitalist giants like the U.S.A., France, West Germany and Japan but also the weak nations in which those industrial nations have investments. Therefore the imperialist camp can be sub-divided into exploiting and exploited countries. For the most part, the nations of Africa fall into the group of exploited countries inside of the capitalist/imperialist system. Roughly one-third of the world's peoples are already living under some form of Socialism. The other two-thirds constitute the capitalist/imperialist camp, with the majority being in the exploited section.

\section{Statement of the Problem}

Most scholars and policy-makers from the industrialized countries of the world have always argued that their development was as a result of their progressive culture, strong democratic institutions and good leadership which are superior to, and are lacking in the Third world. In other words, development in the advanced nations, according to them, is a consequence of their good values, creativity, inventions and innovations. To them, the underdeveloped nations have made no contributions to the development of the industrialized nations, that in fact, even the little development in the Third world is as a result of their contact with the industrialized capitalist West, and without such contact, there would have been no development at all in the Third world without considering the ever-flowing stream of human and material resources from Africa. It is as a result of this misapprehension and surroundings that this paper stands to contend with.

\section{OBJECTIVES OF THE STUdY}

a) To explain underdevelopment in Africa objectively

b) To Point out why some nations are poor and others are rich 
c) To understand the origin of global inequality

d) To know why globalization is affecting different nations of the world, differently

e) To comprehend why Africa is still needed to pilot the political economy by the west

f) To identify the causes of underdevelopment in the Third World nation.

g) To advance some measures in tackling the problem of underdevelopment in Africa.

\section{RESEARCH QUESTIONS}

The study stands to provide suitable answers to the following questions:

a) What is real development/underdevelopment?

b) Why are some nations poor, while others are rich?

c) What is responsible for global inequality?

d) Who benefits most from global economy and globalization?

e) Why is politics and economy central to development and underdevelopment?

f) What are the causes of socio-political and economy crises of development in the Third world nations?

g) How can the underdeveloped states of Africa achieve development?

\section{Conceptual Discourse}

Development', it makes it easier to comprehend the concept of underdevelopment. Obviously, underdevelopment is not absence of development, because every people have developed in one way or another and to a greater or lesser extent. Underdevelopment makes sense only as a means of comparing levels of development. It is very much tied to the fact that human social development has been uneven and from a strictly economic view-point some human groups have advanced further by producing more and becoming wealthier.

According to Walter Rodney (1973), development is an overall social process which is dependent upon increased capacity of members of a society to master the laws of nature (that is science) and apply such laws in the production of tools (that is technology) with which they can control their environment to meet their immediate and future needs. It cannot be seen purely as an economic affair because other segments of the society are also involved.

Development is the gradual, and sometimes rapid metamorphosis of a society from a state of lack to a state of plenty, quality life and happiness. The industrialized countries of the world such as the US, Britain, France, Germany, Russia, Canada, Japan, China et cetera, have achieved development, while it is still a mirage in the Third world countries, especially those in Sub-Saharan Africa. Moreover, what is more desirable to all countries of the globe, today, is not just development, but a development that is sustainable. Sustainable development is that which "meets the needs of the present generation without compromising the ability of the future generations to meet their own needs" (Bruntland Report). It involves the prudent use and conservation of available resources and the transfer of technology and skills as well as national norms and values from one generation to another, Mmaduabuch (2012). Political development connotes the evolution of a political system to a desired state of being characterized by advanced political culture and political structure which entail "cultural secularization" (the process whereby members of the society become increasingly rational, analytical and participant oriented in their political actions) and "structural or role differentiation" (the process whereby old roles are transformed and new types of roles emerged coupled with an expanded capacity of the political system to perform conversion function, system maintenance function and adaptation function). All these are necessary for state-building, nation-building, political participation, economic production, and authoritative distribution of resources. The industrialized Western Societies exemplify political systems where there are cultural secularization and structural differentiation. Underdevelopment is not absence of development, nor the absence of human and natural resources. It means the inadequate or insufficient level of development in the Third world as a result of the exploitation or the under-utilization of their human and material resources, or a combination of both factors. Underdevelopment depicts an appalling situation where the human and socio-economic potentials of a given society have either been externally exploited to the detriment of its inhabitants, or have not been fully or optimally harnesse $\mathrm{d}$ by the government for a better and quality living of its citizens. 
Underdevelopment makes sense only as a parameter for comparing levels of development across the globe. Every society has developed in one way or another. Some societies have developed more by being able to master science and technology and deploy such superior knowledge in the production of tools with which they meet their needs, and even exploit, subjugate and dominate other societies that have "lesser" knowledge of science and technology, and this, directly or indirectly stagnates development process of the latter while accelerating the development of the former.

However, it's germane to adumbrate that the collapse of the eastern bloc in the late 80's and early 90's led to the emergence of a global western system of economies into the global capitalist market economy. After the demise of the eastern Europe in early 90's, capitalism as an economic system now dominate the globe more than it has been used ever at any time in its history.

Development is better understood by examining various areas in which it implies the manifestation of improvement in the conditions of man and society. When so perceived, development may be defined as the manifestation of change in the distinctive character of a phenomenon, resulting in qualitative and quantitative improvement in the nature and conditions of the phenomenon. (Ojo 1998)

Development is an overall social process which is dependent upon increased capacity of members of a society to master the laws of nature (that is science) and apply such laws in the production of tools (that is technology) with which they can control their environment to meet their immediate and future needs. It cannot be seen purely as an economic affair because other segments of the society are also involved, Rodney, 1972).

Todaro, (1985) however, conceptualizes development as: "a multidimensional process involving major changes in social structures, popular attitudes, and national institutions, as well as the acceleration of economic growth, the reduction of inequality and the eradication of absolute poverty" (Lane and Ersson, 1997:19). In another work, the same scholar identifies three core values of development (Todaro, 1989:89-90). These include the ability to provide as many people as possible with their basic needs or the ability to acquire adequate food, shelter, health care and protection. It also entails the perception of individuals or groups of self-worth and esteem as a respected members of the society and freedom in the sense that individuals and society at large have an expanded range of choice, not only with respect to the material necessities for self reproduction, but also in their ability to have a say in, if not to determine, the method and process by which values are allocated in the society (Ogwu, 2002).

Development is the progressive movement from traditional society to the stage of high mass consumption of goods and services. For any human society that wishes to develop, it must go through five stages of development as epitomized by the West, particularly the USA, and these include: (a) Traditional Stage (b) the Transitional Stage (c) the Take-off Stage (d) the Drive to Maturity (e) the Stage of High Mass Consumption. (Rostow, 1960).

\section{THEORETICAL FRAMEWORK}

Every theory of development is distinguished by its perception of the objective of development and the strategy it prescribes to achieve development. Therefore, dependency theory is best option for this work.

Dependency theory is also known as Underdevelopment theory/the Radical School of Thought/the Neo-Marxist theory. It came as a direct response to the short-comings of the Modernization theory in explaining why the core is developed and while the periphery is underdeveloped. Its proponents include; Andre Gunder Frank, Walter Rodney, Frantz Fanon, Samir Amin, Claude Ake, et cetera.

Dependency theory sees development and underdevelopment as two sides of the same coin in the sense that they are the inevitable outcomes and the physical manifestations of the World Capitalist system and its inherent contradictions and exploitations. The theory classified the world into two - the Core or Centre (which is made up of the industrialized capitalist nations), and the Periphery or satellite (which is made up of the colonized and poor countries of the world). Dependency theory argues that the export of capitalism by the West to other parts of the World and its resultant colonialism cum neo-colonialism is responsible for the underdevelopment and dependency of the Third World. Capitalism is driven by the quest for profit maximization, the theory argues. The quest for profit maximization compelled the Europeans to search for cheap raw material, cheap labour and markets for their finished goods. This led to colonialism and the subsequent neo-colonialism through 
which the resources of the colonized were, and are still being exploited. In this regard, Claude Ake in his classic work - A Political Economy of Africa, submits that:

The contradictions of capitalism not only transform it, they also transplant it. The transplanting of capitalism arises from those contradictions which reduce the rate of profit and arrest the capitalization of surplus value. Confronted with these effects, it was inevitable that the capitalist, forever bent on profit maximization, would look for a new environment in which the process of accumulation could proceed apace. Capitalists turned to foreign lands, attacked and subjugated them and integrated their economies into those of Western Europe.

This is perhaps why V. I. Lenin submitted that "imperialism is the highest stage of capitalism". Colonialism and neo-colonialism led to the incorporation of the economies of the colonized peoples in the world capitalist economic system at a subjugated position. This produced two consequences in the world - development in the industrialized capitalist states, and underdevelopment as well as dependency in the colonized or Third world countries.

The process of underdevelopment, laments Immanuel Wallenstein, started as far back as 16th century (1450-1640) during mercantilism and slave trade, and later, colonialism, during which the Western Europe enriched itself with the human and material resources it siphoned from the other continents, particularly from its colonies in Africa and Latin America where millions of slaves and huge raw materials were transferred to Europe. The plunder of Africa, Asia and Latin America by European capitalist, enhanced development in Europe in one hand. On the other hand, it led to underdevelopment of the colonies and their dependency on the former for survival.

That is to say that the development of the Centre is as a result of the exploitation and the consequent underdevelopment of the periphery. Therefore, the relationship between the Periphery and the Centre could be likened to that between a seed and a plant. Just as a seed has to die in order to germinate and give life to plant, the periphery had to be underdeveloped in order to give development to the Centre. But while the relationship between a seed and a plant is natural and symbiotic, that between the Periphery and the Centre is man-made and parasitic.

Andre Gunder Frank, like other Dependency theorists, believes that the Periphery feeds and nourishes the Centre with its cheap labor and cheap primary commodities (cocoa, cotton, palm oil, rubber, groundnuts, crude oil, etc), while the Centre stagnates and under develops the Periphery with its capitalist greed, export of expensive finished goods, un favorable terms of trade and exploitative international politico-economic capitalist policies and institutions such as globalization, the IMF and the World Bank. All these factors individually and collectively, have led to underdevelopment of the Third World Countries and their seeming perpetual dependency on the Industrialized Capitalist States.

Therefore, the Dependency School of Thought recommends that the only way the Third world can achieve development is to "delink" their economies from their source of exploitation and underdevelopment which is the International Capitalist Economic System, and chart a new path to development which should be built on socialist principles rather than on the foundation of exploitation of one country by another which capitalism advances. In his own view, Andre Gunder Frank asserted that the colonizing states constitute the "Centre" of development, while the colonies constitute the "Periphery". Underdevelopment is not original nor the starting point of the periphery, rather it is a result of the stagnation of their development by their contact with Western Capitalist system and colonialism. This contact incorporated the colonies into the world capitalist system at a subjugated position, and thereby created development in the core and underdevelopment in the periphery. The centre (which is capitalist) cannot engender any meaningful development outside its domain. Andre Gunder Frank described this process as "the development of underdevelopment".

In consonance with the above view, Walter Rodney, in "How Europe Underdeveloped Africa" posited that: imperialism was in effect the extended capitalist system, which for many years embraced the whole world - one part being the exploiters and the other the exploited, one part being dominated and the other acting as overlords, one part making policy and the other being dependent.

Moreover, apart from the aforementioned factors which now manifest in the form of globalization, bad leadership and corruption appear to be some of the major causes of underdevelopment in the Third world. Virtually all the countries experiencing underdevelopment today have a history of corruption, bad governance and political imbroglio,(Mmaduabuchi,2012). 


\section{The Truncation of Africa DeVelopment by the West}

The things which bring Africa into the capitalist market system are trade, colonial domination and capitalist investment. Trade has existed for several centuries; colonial rule began in the late 19th century and has almost disappeared; and the investment in the African economy has been increasing steadily in the present century. Throughout the period that Africa has participated in the capitalist economy, two factors have brought about underdevelopment. In the first place, the wealth created by African labour and from African resources was grabbed by the capitalist countries of Europe; and in the second place restrictions were placed upon African capacity to make the maximum use of its economic potential - which is what development is all about. Those two processes represent the answer to the two questions raised above as to why Africa has realized so little of its potential and why so much of its present wealth goes outside of the continent.

African economies are integrated into the very structure of the developed capitalist economies; and they are integrated in a manner that is unfavorable to Africa and ensures that Africa is dependent on the big capitalist countries. Indeed, structural dependence is one of the characteristics of underdevelopment. Most progressive writers divide the capitalist/imperialist system into two parts. The first is the dominant or metropolitan section and the countries in the second group are often called satellites because they are in the orbit of the metropolitan economies. The same idea is conveyed by simply saying that the underdeveloped countries are dependencies of the metropolitan capitalist economies. It has been shown that, using comparative standards, Africa today is underdeveloped in relation to_Western Europe and a few other parts of the world; and that the present position has been arrived at, not by the separate evolution of Africa on the one hand and Europe on the other, but exploitation. As is well known, Africa has had prolonged and extensive contact with Europe, and one has to bear in mind that contact between different societies changes their respective rates of development.

When a child or the young of any animal species ceases to be dependent upon its mother for food and protection, it can be said to have developed in the direction of maturity. Dependent nations can never be considered developed. It is true that modern conditions force all countries to be mutually interdependent in order to satisfy the needs of their citizens; but that is not incompatible with economic independence because economic independence does not mean isolation. It does, however, require a capacity to exercise choice in external relations, and above all it requires that a nation's growth at some point must become self-reliant and self-sustaining. Such things are obviously in direct contradiction to the economic dependence of numerous countries on the metro poles of Western Europe, North America and Japan.

It is also true that metro poles are dependent on the wealth of the exploited portions of the world. This is a source of their strength and a potential weakness within the capitalist/imperialist system, since the peasants and workers of the dependencies are awakening to a realization that it is possible to cut the tentacles which imperialism has extended into their countries. However, there is a substantial difference between the dependence of the metro poles on the colonies and the subjugation of the colonies under a foreign capitalist yoke. The capitalist countries are technologically more advanced and are therefore the sector of the imperialist system which determined the direction of change. A striking example to this effect is the fact that synthetic fabrics manufactured in the capitalist metro poles have begun to replace fabrics made from raw material grown in the colonies. In other words, (within certain limits) it is the technologically advanced metro poles who can decide when to end their dependence on the colonies in a particular sphere. When that happens, it is the colony or neo-colony which goes begging cap in hand for a reprieve and a new quota. It is for this reason that a formerly colonized nation has no hope of developing until it breaks effectively with the vicious circle of dependence and exploitation which characterizes imperialism.

At the social and cultural level, there are many features which aid in keeping underdeveloped countries integrated into the capitalist system and at the same time hanging on to the apron strings of the metro poles. The Christian Church has always been a major instrument for cultural penetration and cultural dominance, in spite of the fact. That in many instances Africans sought to set up independent churches. Equally important has been the role of education in producing Africans to service the capitalist system and to subscribe to its values. Recently, the imperialists have been using new universities in Africa to keep themselves entrenched at the highest academic level. Something as basic as language has come to serve as one of the mechanisms of integration and dependence. The 
French and English that is so widely used in Africa is more for the purpose of African communicating with the exploiters rather than African with African. Actually, it would be difficult to find a sphere which did not reflect the economic dependence and structural integration. At a glance, nothing could be less harmful and more entertaining than music, and yet this tool is used as a weapon of cultural domination. The American imperialists go so far as to take the folk music, jazz and soul music of oppressed black people and transform this into American propaganda over the Voice of America beamed at Africa. During the colonial period, the forms of political subordination in Africa were obvious. There were governors, colonial officials and police. In politically independent African states, the metropolitan capitalists have to ensure favorable political decisions by remote control. The question as to whom and what is responsible for African underdevelopment can be answered at two levels. Firstly, the answer is that the operation of the imperialist system bears major responsibility for African economic retardation by draining African wealth and by making it impossible to develop more rapidly the resources of the continent. Secondly, one has to deal with those who manipulate the system and those who are either agents or unwitting accomplices of the said system. The capitalists of Western Europe were the ones who actively extended their exploitation from inside Europe to cover the whole of Africa. There were several reasons why the African worker was more crudely exploited than his European counterpart in the present century. Firstly, the alien colonial state had a monopoly of political power, after crushing all opposition by armed force. Secondly, the African working class was small, very dispersed, and very unstable owing to migratory practices. Thirdly, while capitalism was willing to exploit all workers everywhere, European capitalists in Africa had additional racial justifications for dealing unjustly with the African worker. The racist theory that the black man was inferior led to the conclusion that he deserved lower wages; and, interestingly enough, the lightskinned Arab and Berber populations of North Africa were treated as 'blacks' by the white racist French. The combination of the above factors in turn made it extremely difficult for African workers to organize themselves.

In addition, Colonial governments discriminated against the employment of Africans in senior categories; and, whenever it happened that a white and a black filled the same post, the white man was sure to be paid considerably more. This was true at all levels, ranging from civil service posts to mine workers. African salaried workers in the British colonies of Gold Coast and Nigeria were better off than their brothers in many other parts of the continent, but they were restricted to the 'Junior staff' level in the civil service. In the period before the last world war, European civil servants in the Gold Coast received an average of $£ 40$ per month, with quarters and other privileges. Africans got an average salary of $£ 4$. There were instances where one European in an establishment earned as much as his twenty-five African assistants put together. Outside the civil service, Africans obtained work in building projects, in mines and as domestics - all low-paying jobs. It was exploitation without responsibility and without redress. In 1934, forty-one Africans were killed in a gold mine disaster in the Gold Coast, and the capitalist company offered only $£ 3$ to the dependants of each of these men as compensation.

The differences between the prices of African exports of raw materials and their importation of manufactured goods constituted a form of unequal exchange. Throughout the colonial period, this inequality in exchange got worse. Economists refer to the process as one of deteriorating terms of trade. In 1939, with the same quantity of primary goods colonies could buy only $60 \%$ of manufactured goods which they bought in the decade 1870-80 before colonial rule. By 1960, the amount of European manufactured goods purchasable by the same quantity of African raw materials had fallen still further. There was no objective economic law which determined that primary produce should be worth so little. Indeed, the developed countries sold certain raw materials like timber and wheat at much higher prices than a colony could command. The explanation is that the unequal exchange was forced upon Africa by the political and military supremacy of the colonizers, just as in the sphere of international relations unequal treaties were forced upon small states in the dependencies, like those in Latin America. Channels for the exploitation of surplus were not exhausted by the trading companies and the industrial concerns alone, but the shipping companies constituted a larger exploitative channel that cannot be overlooked. The largest shipping companies were those under the flags of the colonizing nations, especially the British. Shipping companies retained a high profit margin by a practice similar to the 'pools' of the commercial firms. They established what were known as 'Conference Lines' which allowed two or more shippers to share the freight loads between themselves on the most favorable basis possible. 
The African peasant or worker had no access to bank loans because he had no 'securities' or 'collateral'. Banks and finance houses dealt only with other capitalists who could prove to the bankers that whatever happened the bank would recover its money and make a profit. In the epoch of imperialism, the bankers became the aristocrats of the capitalist world, so in another sense, they were very much in the foreground. The amount of surplus produced by African workers and peasants and passing into the hands of metropolitan bankers is quite phenomenal.

In recent times, they were joined and to some extent replaced by capitalists from the United States; and for many years now even the workers of those metropolitan countries have benefited from the exploitation and underdevelopment of Africa. None of these remarks are intended to remove the ultimate responsibility for development from the shoulders of Africans. Not only are there African accomplices inside the imperialist system, but every African has a responsibility to understand the system and work for its overthrow.

\section{The Inequality of Global Capitalism}

Some would argue that Africa has never freed itself from domination by the west. In the late twentieth century and in the twenty first century, the relationship between the west and Africa has been primarily one of exploitation. International trading agreements with Africa have been unfair on African countries. These agreements have been overly influenced by western big businesses. Such unfair agreements and relationships have allowed individual African officials to get rich while the region sells itself cheaply and develops no infrastructure.

This relationship of exploitation has been a common feature of the European intervention in Africa. It started with the arrival of the missionaries, and continued with the arrival of European merchants and mercenaries, and most lately, with the western multinational corporations.

The Third world nations particularly those in Africa are underdeveloped today not because of the incorporation of their economies into the global capitalist system, but because of "how" their economies were incorporated. Colonialism and neo-colonialism disarticulated and monetized the Third world economies and made them to be part of the global capitalist economy at a subjugated position. From the out-set, their economies were designed to produce mainly primary commodities or raw materials to service the industries in the Metro poles. The Metro poles or advanced capitalist economies were designed to produce finished goods that are marketable both in the Periphery and in the Core or Centre.(Mmaduabuch,2012).

On top of this, many multinational corporations do not even sell African products using prices established by the laws of supply and demand in a free market. Increased costs of production are not passed onto the consumers who buy the produce; instead they are sold from the source in Africa at a lower rate which means less income for African workers and business. The global market also sets a price on most of Africa's exports and so the higher production cost cannot be recouped. At the same time, a rise in productivity wills not necessarily lower world prices by an increase in supply, because the demand may remain fairly small. Africa has mostly been caught in this economic cycle. This is a fundamental inequality in international trade and once this has been set up it is difficult to change.

To sum up, we can say that an unequal trading system has been imposed on Africa by Europe from the mid fifteenth century onwards. This unequal trading system, in one form or another, continues today. It has meant that African countries have never built up sufficient national wealth to invest in their infrastructure (in things such as roads and electricity supply) and industry so that they can develop as countries properly.

Table1. World Merchandise Trade in 2015

\begin{tabular}{|l|l|l|}
\hline REGIONS & EXPORT VALUES IN DOLLARS & WORLD TRADE \\
\hline Europe & 5.6 trillion & $38 \%$ \\
\hline Asia & 4.6 trillion & $32 \%$ \\
\hline North America & 1.9 trillion & $13 \%$ \\
\hline Middle East & 916 billion & $6 \%$ \\
\hline CIS (Russia and Ukraine) & 588 billion & $4 \%$ \\
\hline South America & 575 billion & $4 \%$ \\
\hline Africa & 500 billion & $3 \%$ \\
\hline TOTAL & 14.679 trillion & $100 \%$ \\
\hline
\end{tabular}

Source: World Trade Organization (Wto) 2013 Press Release 


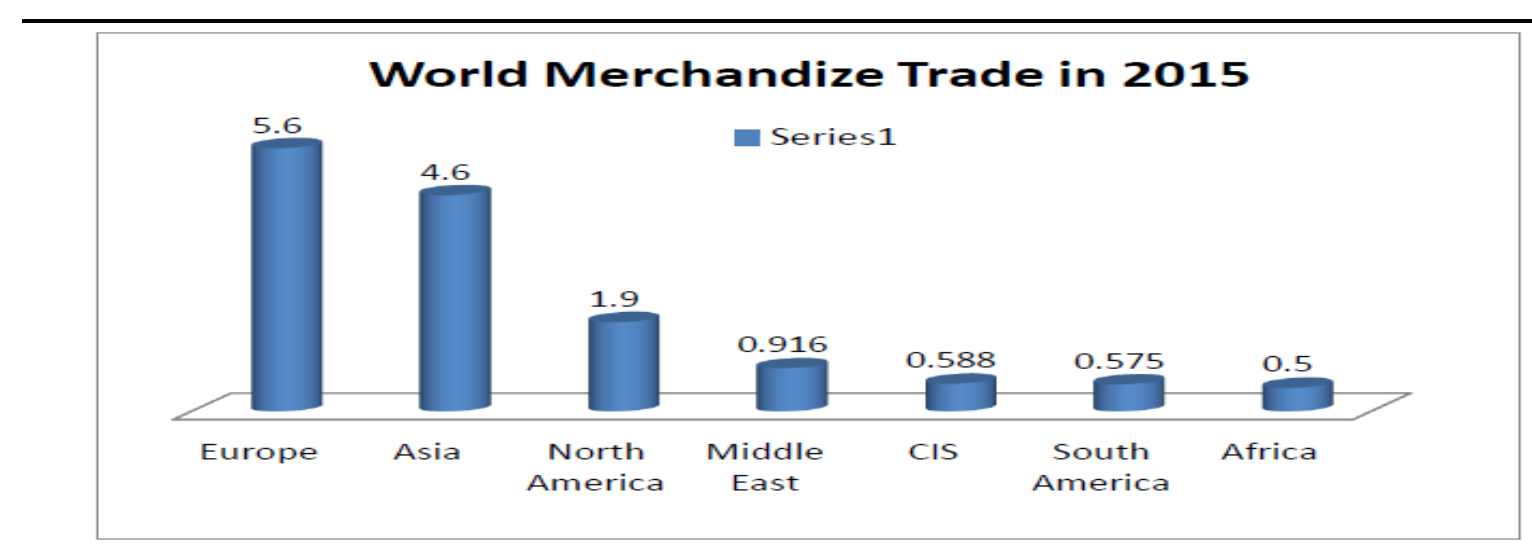

Figure1.

The above table gives a clear picture of the gap between Africa and other continents measured in terms of trade. It is the gap that allows one group to be called 'developed' and another 'underdeveloped'. The gap that can be seen from the above evidence is not only great, but it is also increasing. Many people have come to realize that the developed countries are growing richer quite rapidly, while underdeveloped countries for the most part show stagnancy or slow rates of growth. It is obvious that in 2015 Africa contributed only 3\% to the global trade. In 2016 and 2017, Africa's contribution has even fallen to less than $2 \%$. The reason is not because its goods are too small in terms of quantity, or amount of time and energy spent on their production, but because its goods are mainly primary products which are usually under priced by the industrialized nations. This is unlike finished goods from the industrialized world whose prices are very high as fixed by them.

Not even the World Trade Organization (WTO) which came into existence in 1995 to address the deficiencies and the inherent prejudices of the Defunct General Agreement on Trade and tariffs (GATT) which was established in 1948 to regulate trade among nations, has been able to tackle this injustice. Not even the creation of World Trade Tribunal by WTO to address and redress disputes and breaches of rules and regulations arising from international trade could right this protracted wrong in global trade relations.

\section{ECONOMIC LEGACY OF COLONIALISM}

Developed economies have certain characteristics which contrast with underdeveloped ones. The developed countries are all industrialized. That is to say, the greater part of their working population is engaged in industry rather than agriculture, and most of their wealth comes out of mines, factories, etc. They have a high output of labour per man in industry because of their advanced technology and skills. This is well known, but it is also striking that the developed countries have a much more advanced agriculture than the rest of the world. Their agriculture has already become an industry, and the agricultural part of the economy produces more although it is small. The countries of Africa, Asia and Latin America are called agricultural countries because they rely on agriculture and have little or no industry: but their agriculture is unscientific and the yields are far less than those of the developed countries. In several of the largest underdeveloped nations, there was stagnation and fall in agricultural output in and after 1966. In Africa, the output of food per person has been falling in recent years. Because the developed countries have a stronger industrial and agricultural economy than the rest of the world, they produce far more goods than the poor nations-in the category of necessities as well as luxuries. It is possible to draw up statistical tables showing the production of grain, milk, steel, electric power, paper, and a wide range of other goods; and showing at the same time how much of each commodity is made available to each citizen (on the average). Once again, the figures are highly favorable to a few privileged countries in the world.

African countries still lack democratic representation in the decision-making processes of the postwar international institutions. This is confirmed by the findings from a survey done by UNECA that shows that the majority of the respondents (57\%) view the current economic governance structures as not facilitating their effective participation in the global economy. African Least Developed Countries are even more skeptical, with two-thirds of the respondents expressing the view that the current structure of global governance does not allow for their effective participation in norm setting in the key financial, monetary and multilateral institutions. 
For example, almost a quarter of the IMF's membership comes from sub-Saharan Africa (45 countries), yet the total voting power of this bloc is estimated to only $4.4 \%$. Even in those decisions that directly affect sub-Saharan African countries, these countries do not have enough voting power to sway the decision in any direction, and they have to rely on the support of other developing countries to muster sufficient support for their position, Carin and Fantu ,(2008), The Commission on Global Governance and many other similar international panels have proposed numerous innovative proposals on how to democratize the current global governance architecture. Unfortunately, the major shareholders of the IMF and the World Bank have been unwilling to let go of the levers of power they have vis-à-vis other developing countries in these institutions, particularly in the face of the emergence of more assertive developing countries such as Brazil, China, India and South Africa.

For developing countries, trade liberalization was part and parcel of the adjustment reform programs already underway. It was expected that trade liberalization would boost economic growth in poor countries, by providing access to foreign exchange, expanding markets, increasing foreign direct investment and facilitating the transfer of technology. This would in turn boost domestic productivity, create employment and increase domestic incomes. Needless to say, these supposed benefits from openness and free trade have yet to materialize in Africa in a meaningful way.

Despite the elimination of many barriers that have restricted international trade in goods, significant barriers to trade still persist - often to the detriment of the poorest countries. These barriers include basic issues such as market access to the development countries' economies, terms of trade distortions, commodity price volatility and trade patterns, phasing-out export subsidies and trade distorting domestic support measures in agricultural exports, and special and differential treatment for poor countries. These concerns were supposed to be addressed under the so-called 'Doha Development Round'. Sadly, after almost eight years of on-and-off negotiations, Carin and Fantu,(2008), the Doha Round of trade negotiations collapsed on the evening of July 29, 2008 when some of the leading developed countries refused to agree on a proposal to reduce their 'agricultural subsidies' as well as to agree on a Special Safeguard Mechanism (SSM) that developing countries wanted to protect their farmers from sudden surges of agricultural imports.

In the final analysis, with a level playing field, trade can be a much greater force than aid in reducing poverty in Africa. Yet the developed countries have consistently refused to level the playing field. The disastrous collapse of the EU-Africa Summit in December 2007 over disagreement over the heavily EU-biased Economic Partnership Agreement, the breakdown of the negotiations of the Doha Development Round in July 28 this year can only help further solidify the growing perception of globalization as colonialism. Without rebalancing the 'unbalanced rules', African countries cannot expect to benefit from expanded global trade.

\section{The SupPosed Benefits of COLONiALiSM To AFriCa}

According to George Padmore, (West Indian) Pan-Africanist, in 1936 quoted that,' the black man certainly has to pay dear for carrying the white man's burden.

It appeals to the common sentiment that 'after all there must be two sides to a thing'. The argument suggests that, on the one hand, there was exploitation and oppression, but, on the other hand, colonial governments did much for the benefit of Africans and they developed Africa. It is our contention that this is completely false. More than three decades after most African nations became independent; there is no consensus on the legacy of colonialism. With most African countries still only tottering on their feet and many close to collapse, some people ask whether the problem is due to Africa's colonial experience or inherent adequacies of the African? For apologists of colonialism the answer is simple. Whatever may have been the shortcomings of colonial rule, the overall effect was positive for Africa. Sure, the colonial powers exploited Africa's natural resources but on the balance, colonialism reduced the economic gap between Africa and the West, the apologists argue. Colonialism laid the seeds of the intellectual and material development in Africans. It brought enlightenment where there was ignorance. It suppressed slavery and other barbaric practices such as pagan worship and cannibalism. Formal education and modern medicine were brought to people who had limited understanding or control of their physical environment. The introduction of modern communications, exportable agricultural crops and some new industries provided a foundation for economic development. Africans received new and more efficient forms of political and economic organization. Warring communities were united into modern nation-states with greater opportunity of survival in a competitive world than the numerous mini entities that existed before. Africa is in political and 
economic turmoil today, defenders of imperialism say, because it failed to take advantage of its inheritance from colonial rule. It was, they summarize, Africa's inadequacies that made colonization necessary and the outcome of post-independence self-rule suggests that the withdrawal by the colonial powers was premature.

Colonialism had only one hand which is a one-armed bandit.

What did colonial governments do in the interest of Africans? Supposedly, they built railroads, schools, hospitals and the like. The sum total of these services was amazingly small. Statistics had shown that Africa today is underdeveloped are the statistics representing the state of affairs at the end of colonialism. For that matter, the figures at the end of the first decade of African independence in spheres such as health, housing and education are often several times higher than the figures inherited by the newly independent governments. It would be an act of the most brazen fraud to weigh the paltry social amenities provided during the colonial epoch against the exploitation, and to arrive at the conclusion that the good outweighed the bad.

Furthermore, the limited social services within Africa during colonial times were distributed in a manner that reflected the pattern of domination and exploitation. First of all, white settlers and expatriates wanted the standards of the bourgeoisie or professional classes of the metro poles. They were all the more determined to have luxuries in Africa, because so many of them came from poverty in Europe and could not expect good services in their own homelands. In colonies like Algeria, Kenya and South Africa, it is well known that whites created an infrastructure to afford themselves leisured and enjoyable lives. It was also true that the hulk of the social services went to whites. The southern part of Nigeria was one of the colonial areas that were supposed to have received the most from a benevolent 'mother country'. Ibadan, one of the most heavily populated cities in Africa, had only about 50 Europeans before the last war. For those chosen few, the British colonial government maintained a segregated hospital service of 11 beds in well-furnished surroundings. There were 34 beds for the half-a-million blacks. The situation was repeated in other areas, so that altogether the 4,000 Europeans in the country in the 1930s had 12 modern hospitals, while the African population of at least 40 million had 52 hospitals.

In the area of education, the colonizers did not introduce education into Africa: they introduced a new set of formal educational institutions which partly supplemented and partly replaced those which were there before. The colonial system also stimulated values and practices which amounted to new informal education. The main purpose of the colonial school system was to train Africans to help man the local administration at the lowest ranks and to staff the private capitalist firms owned by Europeans. In effect, that meant selecting a few Africans to participate in the domination and exploitation of the continent as a whole. It was not an educational system that grew out of the African environment or one that was designed to promote the most rational use of material and social resources. It was not an educational system designed to give young people confidence and pride as members of African societies, but one which sought to instill a sense of deference towards all that was European and capitalist. Education in Europe was dominated by the capitalist class. The same class bias was automatically transferred to Africa; and to make matters worse the racism and cultural boastfulness harboured by capitalism were also included in the package of colonial education. Colonial schooling was education for subordination, exploitation, and the creation of mental confusion and the development of underdevelopment.

\section{CONCLUSION AND RECOMMENDATIONS}

Colonialism fettered the development of the enslaved peoples. To facilitate colonial exploitation, the imperialists deliberately hampered economic and cultural progress in the colonies; preserved and restored obsolete forms of social relations, and fomented discord between nationalities and tribes. However, the drive for super profits dictated development of the extractive industry, plantations and capitalist farms, and ;he building of ports, railways and roads in the colonies. In consequence, social changes took place in the colonies, irrespective of the will of the colonialists. New social forces emerged - an industrial and agricultural proletariat, a national bourgeoisie and intelligentsia. The recent global financial crunch has opened the eyes of many leaders of various countries to see the complex social and environmental consequences of unrestrained markets which globalization advocates for. Global capitalism which is today in the guise of globalization is founded on the foundation of exploitation of many by a privileged few, and that is partly 
responsible for the global inequalities and the resultant class struggle cum development crisis across the world. Therefore, it behooves the Third world nations to exercise some caution while dealing with globalization otherwise they will be totally consumed by it. It is also worthy to note here that the Third world countries especially those in Africa are not yet ripe for full liberalization and globalization.

The paper therefore, concludes that the reduction of state to a minimalist status as prescribed by globalization will eventually lead to the crucifixion of the state. But economies in the Third world particularly those in Africa still require the full attention of the state or government to provide not only the enabling ecology for businesses to thrive, but also the ever-needed adequate regulations. Allowing the market forces to regulate African economies with their weak institutions will only result in further exploitation, hardship and underdevelopment.

It is clear that the international monetary machines such as the IMF and World Bank are double edged sword which in one hand support global development, but on the other hand contribute to the underdevelopment of the Third world through its policies. The paper therefore, concludes that the International Financial Institutions such as IMF and World Bank are more or less veritable instruments in the hands of the advanced capitalist countries for deepening dependency and underdevelopment in the Third world states particularly those in Africa. Thus, they should be reformed in such a way that their policies will always benefit both the rich and the poor countries of the world irrespective of a country's financial contribution to the institutions or voting power in the institutions.

More so, from the prevailing social realities, it was discovered that the activities of MNCs in the Third world contribute or furthers underdevelopment mostly in Africa continent. that the on-going underdevelopment crisis in the Third world is partly caused and deepened by the exploitation of the Third world resources by the MNCs together with their conspirators - the comprador bourgeoisie

It also shows that Foreign aid and loans to African states serve more interest to the donors and less interest to the debtors. The politics of foreign aid and debt is used not only to unduly influence African economy, but also to control its resources for the benefits of the advanced nations of the world. The paper therefore, infers that foreign aid and debt have done more harm than good to Africa's development.

Finally, it is very clear that apart from colonial legacies, there are also internal factors such as corruption and political instability which are strong impediment to Africa's development. It is therefore high time that African political leaders stopped blaming imperialism for the continent's economic woes. It behooves the African political leadership to rise up to the occasion through self rebirth and self-designed development strategies to rescue Africa from the abyss of poverty and underdevelopment.

It is evident that if African states can successfully implement the series of reforms advocated above, development will be achieved in no distance time.

\section{REFERENCES}

[1] Akagwu, J.Y (2002), Africa and Global Competitiveness the Post Express, Monday, March 18, Lagos.

[2] Ake C. (1982), Social science as imperialism (Ibadan University Press)

[3] Ake, C. (1979). Social Science as Imperialism: the Theory of Political Development. Ibadan: Ibadan University Press

[4] Alassane, D. O (1997). The challenges of globalization for Africa .A speech delivered at the Southern Africa Economic Summit, sponsored by the World Economic Forum Harare, May 21,

[5] Babawale, T. (2007) Nigeria in the Crises of Governance and Development: Retrospective, Prospective

[6] Analysis of Selected Issues and Events. The Political Economy of Development, Governance and Globalization. Volume 1, 2 Lagos: Concept Publications.

[7] Carin, N. and Fantu, C .(2008), Ph.D. Research Director, The Nordic Africa Institute Uppsala

[8] Ekeh, P.P. (1983), Colonialism and Social Structure Text of Inaugural Lecture, Ibadan: University Press. 
[9] Colonalism and the two Publics in Africa: A Theoretical Statement Comparative Studies in Society and History, 17(14).

[10] Fafowora, T. J. (1998). The Concept of Globalisation in Africa (Socio-Economic Theory).

[11] Fage, J.D. (1997), A History of Africa (3rd Ed), London and New York: Routledge.

[12] Frank, A. G (1989). The Development of Underdevelopment. Oxford: Oxford University Press

[13] Mamdani, M. (2002), Citizen and Subject: Africa and the Legacy of Late Colonialism, Ibadan: John Archers, book.

[14] Mazrui A. (1980), The African condition. (London; Heinemann Educational Books Ltd)

[15] Mkandawire, T. (1988), the road to crisis, adjustment and de-industrialization: the African case. Africa Development, vol. 13, No. 1.

[16] Mmaduabuch, G.S.O (2012), Politics of Development and Under development, NOUN course Manual, Pol 324.

[17] Ogwu, J. (2002), the African Union and the Challenge of Development in the 21st Century, Public Lecture Series No 1, Dept of Political Science, University of Ilorin. PEFS

[18] Ojo, S.O.J (1998), Theoretical Perspective in the study of Development, a Monograph series. IMPRINT SERVICES, Benin City.

[19] Omotola, S. J (2010), Globalization, New Regionalism and the Challenge of Development in Africa, journals of Africana, vol.1

[20] Onimode, B. (2000) Africa in the World of the 21st Century Ibadan: Ibadan University Press. (1989) A Political Economy of African Crisis, London: Zed Press.

[21] Osaghae, E.E. (1999), The Post Colonial State and its Problems" in McGowan, et al (eds) Power, Wealth and Global Order, Cape Town: University of Cape Town Press. (1989) The Character of the State, Legitimacy Crisis and Social Mobilisation in Africa: An Explanation of Form and Character Journal of African Development, 14(2).

[22] Osterhammel, J. (1997), Colonialism: A Theoretical Overview, Kingston: Wiener, princeton and Randle Publishers.

[23] Rimmer, D. (1995), The Effect of Conflict, II: Economic Effects in Oliver, F. (ed) Conflict in Africa, New York and London: Tauris Academic Studies.

[24] Rodney, W. (1972), How Europe Underdeveloped Africa, Dar-es-Salaam: Tanzania Publishing House.

[25] Rodney, W. (1973). How Europe Underdeveloped Africa. London: Bogle-L' Overtures Publications transcrobed by Joaquien Arriola.

[26] Rostow, W.W (1960). The Stages of Economic Growth: A Non-Communist Manifesto. Cambridge: Cambridge.

[27] Wagaki, M. (1995), Who Gains and Losses from Globalization of the Economy? Econews Africa, Vol. 4, no. 20, December, 1995

[28] World Bank (1994), World Debt Tables 1994- 95 Washington DC.

[29] World Bank (2009), Economic Growth in the 1990s: Learning from a Decade of Reform. World Bank, Washington, D. C.

[30] WTO (2015). Trade Growth to Ease in 2011, But Despite 2010 Record Surge, Crisis Hangover Persists

Citation: Ezekiel Elton Michael, Micah et al. "Political Economy of The West And Africa UnderDevelopment Sydrome In The 21St Century." International Journal of Humanities Social Sciences and Education (IJHSSE), vol 4, no. 8, 2017, pp. 1-14. doi:http://dx.doi.org/10.20431/2349-0381.0408001.

Copyright: $\odot 2017$ Authors. This is an open-access article distributed under the terms of the Creative Commons Attribution License, which permits unrestricted use, distribution, and reproduction in any medium, provided the original author and source are credited. 